\title{
Regarding Smart Cities in China, the North and Emerging Economies-One Size Does Not Fit All
}

\author{
Nigel J. W. Browne ${ }^{\mathbb{D}}$ \\ Institute for Housing and Urban Development Studies (IHS), Erasmus University Rotterdam (EUR), \\ 3062 PA Rotterdam, The Netherlands; n.browne@ihs.nl
}

Received: 16 February 2020; Accepted: 30 March 2020; Published: 1 April 2020

\begin{abstract}
This article explores the significance of the "Smart city" concept by reviewing its key components, namely: Internet of Things (IoT), big (urban) data, and urban informatics/analytics, which are discussed against the background of two ongoing trends impacting everyone in the world - the Fourth Paradigm (the digital revolution) and rapid urbanization. China is seen as a great success story in the sense of how urbanization has driven a significant improvement in the economic wellbeing and prosperity of many of its citizens. Chinese expansion has come at a cost, and the question remains concerning the sustainability of the Chinese model. Along with this, the article suggests some of the short comings of the components of the Smart city concept and reflects on the human resource skills that will be required to implement Smart cities in the north. This is contrasted with the piecemeal way in which elements of the Smart city are being implemented in emerging economies. A process that very much seems to reflect fundamental technical and capacity issues that may hinder any blanket application of the Smart city in the emerging economies for a long time.
\end{abstract}

Keywords: urbanization; Fourth Paradigm; China; emerging economies; Smart cities; capacity building

\section{Introduction}

This article is about the main building blocks of Smart cities: Internet of Things (IoT), big (urban) data, and urban informatics. Tony Blair, the former Labor U.K. Prime Minister recently noted the following, "The single greatest thing that is happening in this country, or will happen in the next few years, as with every modern developed country, is the technological revolution. It is going to change everything. We have got to be masters of this." [1].

He is speaking about the so-called Fourth Paradigm. As a qualitative opinion piece, this article also includes the issue of worldwide urbanization as the second major issue, adding context to the discussion. Together, these two processes represent the backdrop against which the above-mentioned building blocks of Smart Cities are examined. The place of China in the discussion is contrasted with the increasing pressure worldwide for sustainable development, a sentiment echoed in the words of former United Nations (UN) Secretary General Ban Ki-moon, "Our struggle for global sustainability will be won or lost in cities" [2].

This article suggests that the capacity building and training of urban managers to implement Smart city strategies worldwide needs further attention. The specific contexts of cities in China, the north, and emerging economies will all require differing approaches. It is an illusion to think that one size fits all.

\section{Methods}

The literature reviewed draws on books; journal articles; and reports on IoT, big (urban) data, and urban informatics/analytics, much of it specifically on Smart cities. The articles cover a period 
ranging from 2009 to 2019, with over two thirds (46) of the articles cited being within the last five years. This qualitative evaluation aimed to get an idea of what is meant by IoT, big (urban) data, and urban informatics/analytics, along with what are the key challenges, as well as an understanding of the hype that exists around these concepts. Two tables in the Supplementary Data include quotes from the literature under the following headings: IoT [3-13], Big (Urban) Data [3,5,7,9,12,14-27], Urban Informatics/Analytics [3,9,12,14,21,22,24,25,28-37], Hype (claims) [3,7-11,14,15,17,21,28,34,38-40], and Challenges $[3,6,7,11,12,14-19,22,24-26,28,35,36,39,41-48]$. The quotes included in the table were used to generate word clouds for each of the five headings in order to visualize the concepts, as discussed in the literature. No verbatim account follows on the various arguments and definitions provided, as the aim is to just get a flavor of the concepts through the word cloud visualizations. A quantitative analysis of these text tables was not undertaken. The discussion subsequently focuses on the variations in the Smart city concept arising from the clear differences in the manifestations of urbanization in China, the north, and in emerging economies. China is used as an example of a country that has embraced both urbanization and the increasingly pervasive digital revolution. Another key issue is to what extent the Smart city concept requires the development of new skillsets among urban managers, and in their absence, what needs to be done to fill the obvious gaps in the training needs of those running cities. Equally pertinent is what does this imply for emerging economies that tend to lack the economic, technical, and human resources needed to embrace the Smart city approach? The discussion here will not cover IT architecture, meaning any specific hardware and software configurations behind the technology. For the purposes of brevity, issues around privacy are assumed as being understood, especially in the light of the recent controversy around social media platforms such as Facebook. Furthermore, the issues around the open data movement are beyond the scope of this article.

\section{The Fourth Paradigm}

Just like urbanization, the current digital revolution, as the quote from Tony Blair illustrates, receives a lot of attention. The so-called Fourth Paradigm of scientific discovery revolves around exploratory research, whereby data is the driving force, and this contrasts to previous research paradigms that rely on describing, developing hypotheses, and using surveys and field observations. When discussing the qualitative approach, Barthelemy observes, "This is where a game changer enters the arena: huge amounts of data on every possible aspect of cities have suddenly (at the human scale) become available." [49] (p. xiii).

Some commentators even go as far to view big data as a strategic economic resource, along the lines of gold and oil [19].

There are three basic interlinked concepts that recur in the literature. These are IoT, big (urban) data, and urban informatics/analytics. Put simply, urban (data) informatics/analytics facilitates the storage and processing of data from the IoT, with applications contributing raw big data towards a specific dataset. Any big data that is collected and stored undergoes preparation to form a dataset before it is ready to be analyzed, using the tools at the urban data analysis stage (informatics). Big data is about bringing together a variety of data sources, ranging from administrative data from governments and businesses, which are now freely accessible to everyone. Added to this is the wide range of often real-time data from sensors that are now embedded in the digital infrastructures of cities. These days, it can be a combination of data from apps and other online data sources, such as social media, that create a comprehensive dataset that can be analyzed to address specific urban issues. The main problem is how to deal with such vast amounts of data. Subsequently, its collection and storage should lead to datasets that can offer insights to the urban problems in the appropriate context. Creating context is one of the main challenges. The IoT represents, in our rapidly connected and digital world, one of the main contributors to the upsurge in the availability of big (urban) data. It can be used by the taxis in New York, using GPS-type location information to provide cities with vital real-time traffic information, and it can be used in cities like Kuala Lumpur for citizens to book and plan trips using the taxi service Grab. These types of innovations represent the main areas where emerging 
economies can benefit and leapfrog by deploying app-based innovations to inform and improve their own urban experience. The Figure 1 below is one of the word clouds generated from terminology from the literature.

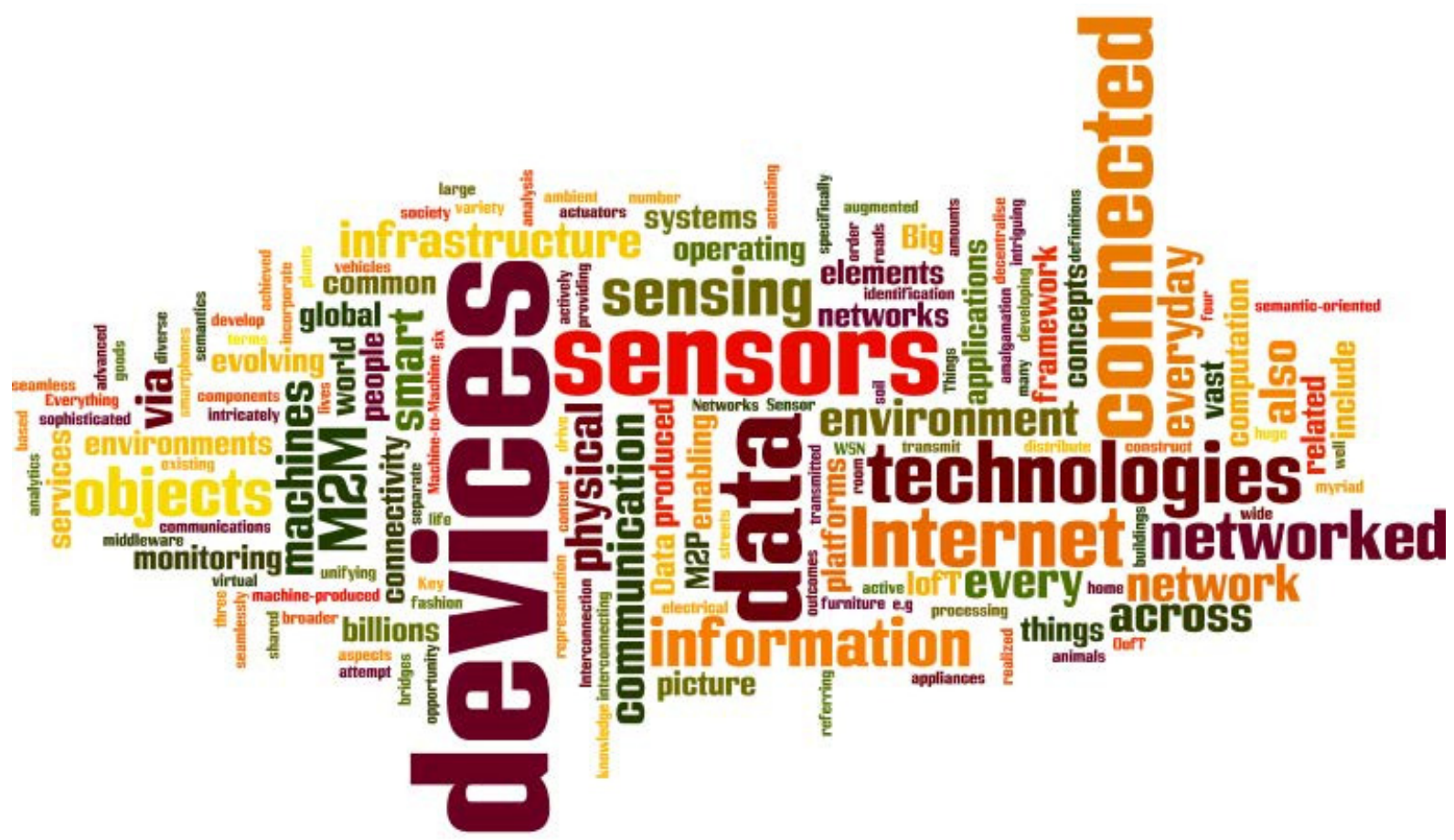

Figure 1. Internet of things (IoT) word cloud generated by the Wordle App.

Urban informatics/analytics is basically about computer science and the techniques needed to collect, store, and manage huge amounts of big data, including that generated from IoT, and applying specialized techniques to extract useable knowledge to inform urban management policy and planning. Many definitions focus on the use of statistical techniques and visualization using software packages such as R. R represents an integrated suite of software facilities for data manipulation, calculation, and graphical display. It encompasses a data handling and storage facility. It is often used for a single piece of data analysis. Currently, there are about 25 packages supplied with $R$ that have the label of "standard" and "recommended" packages. It is open-source software. [50] Together with other tools such as data mining and artificial intelligence (AI), along with other techniques, the expectation is that such techniques will enable huge data sets to be analyzed and will yield meaningful understanding for city authorities and urban managers. Much of the literature focuses on this potential, however, not only technological challenges may impede progress, but equally important will be the capacity at the level of municipal governments to engage employees with the right skillsets to be able to accommodate, understand, and implement urban policy decisions based on applying the lessons learned from the analysis of big (urban) data. To date, there is an acute shortage of urban managers with such skillsets. Apart from the obvious technological challenges, the institutional capacity shortage at the level of the municipal government should not be underestimated. The claims around the huge potential of urban informatics are very much mirrored by a high degree of skepticism around such claims. Apart from the considerable technical issues needing resolution, particularly around data curation, as was pointed out above, gaps in the skillset of those who are going to use the knowledge generated from big urban data analytics may prove to be a major obstacle requiring urgent attention. The Supplementary Data for this article includes other word clouds on big urban data, urban informatics/analytics, hype (claims), and challenges. 


\section{Urbanization}

Urbanization represents one of the major ongoing processes in recent human history, with the shift in the world from being primarily rural to more urban. Various authors in the literature cite this fundamental change, dating from 2008, [3,7,31,46,49,51,52], and the projection is that by 2050, 70\% of the world will be living in urban areas or cities. The key argument being that global urbanization has radically changed how humans interact with each other and the natural environment. This change has led to a plethora of issues and challenges in the realm of urban planning and management. In addition to this, one of the biggest problems is to be able to grasp the scale of this shift. One indication is that by 2050 , it is estimated that nearly $40 \%$ of the projected urban population growth will take place in only three countries, namely China, India, and Nigeria [37].

Cities have, in terms of scaling and densities, some distinct advantages to enable them to take advantage and leverage their economic clout in areas of resource efficiencies, green city planning, and low-carbon urban mobility via mass public transport systems. On the downside, cities are key producers of pollution, especially at coastal locations, and are vulnerable to natural disasters as a result of climate change. They account for nearly $70 \%$ of the global energy consumption and are responsible for more than three-quarters of greenhouse gas emissions, and at the same time, they have serious social problems arising from urban poverty, linked to the fact that the urban poor (1 billion people) are often located in slum areas susceptible to natural disasters, and on top of that, slum dwellers often do not have adequate infrastructure, particularly in terms of water and sanitation facilities. [53]. For this reason, any new research paradigm should embrace the higher goals of sustainability, as encompassed in the United Nations Sustainable Development Goals (SDGs), particularly SDG 11, and not have economic gain as its only driving force. The $11^{\text {th }}$ SDG is about making cities and human settlements inclusive, safe, resilient, and sustainable [54]. It is time to put the issues of urbanization on the map, and for the realization to hit home that our finite resources are beginning to run out.

\section{Is China a Unique Case?}

In a recent commentary, Hamnet emphasizes the unique character of Chinese urbanization, stressing the key role played by the party and state and the way in which state ownership of land fuelled the financing of the unprecedented rapid urbanization of the country. This means that Chinese urbanization is basically different from the rest of the world [55]. This makes it the more remarkable that many scientific journals are including articles on what is happening in the country. A simple sum from four main urban journals illustrates the extent to which the Chinese model is being written about by academics, as shown in the Table 1 below:

Table 1. Number of articles in 2019 on China in four main urban scientific journals.

\begin{tabular}{cccc}
\hline Journal Volume 2019 & Number of Articles & Number of Articles on China & Percentage \\
\hline Urban Studies & 200 & 20 & $10 \%$ \\
\hline Housing Studies & 103 & 5 & $4.85 \%$ \\
\hline Habitat International & 105 & 55 & $52.38 \%$ \\
\hline Cities & 301 & 77 & $25.58 \%$ \\
\hline
\end{tabular}

This provides some indication on the degree to which urban scholars are writing about China. Hu speaks of there being a lack of institutional adaptation in China, as well as reiterating the social and environmental problems arising from China's rapid urban transformation, and the disadvantages this has in terms of sustainability [56]. He also observes that even though China has a burgeoning Smart cities program, these programs do not really seem to engage international scholarship. There is a lack of critical literature on how China's Smart cities are developing, and in addition, limited reflection on what lessons it could offer other countries interested in Smart cities. Hu points out that the 
"wicked problems" relating to climate change, urbanization, quality of life, and social inequalities are not addressed enough in the Chinese Smart city programs, and he urges that Smart city performance measures need to include goals on environmental, economic, and social sustainability. His mantra appears to be moving away from focusing only on economic growth to a mode that encompasses urban sustainability in urban policy. He suggests that the Chinese model of Smart cities is more technological, aiming to improve efficiency and effectiveness in urban management and economic advantages. Any attempt to take on the sustainability issues facing Chinese cities is lacking. What also makes Chinese Smart cities distinct is the political driving force of the Chinese government. This makes it an urban regime that is rather different from the West. Although maybe having some technological success, the Chinese model's weakness appears to be its inability to establish genuine public participation and to address the previously mentioned wicked problems [56].

China's policy is to transform itself into an entrepreneurial state that aggressively follows economic development and urban growth to drive its progress [57]. As suggested above, the unprecedented urban explosion in China cannot be ignored. This article aims to put into perspective what has happened in China, and to try and understand what it might all mean for the implementation of the Smart city concept elsewhere in the world. Urbanization has been particularly prolific in China without a doubt. As with big (urban) data, the extent of urbanization in China is very difficult to fully fathom. According to a report by the McKinsey Global Institute, of the 858 cities in China today, only 13 have populations above 5 million. However, these 13 contributed towards more than a quarter of the country's GDP in 2007 [51]. The same report goes on to predict that by 2025 in the region of China, 225 cities alone will be responsible for around 30\% of the world's projected increase in GDP [51]. Another figure that is mentioned is the prediction that by 2030, China will have 221 cities of more than 1 million inhabitants [58]. It is difficult to get our head around these figures and comprehend their significance. Put another way, China alone has over $20 \%$ of the world's population and is the one country that is urbanizing much faster than any other country in history. The McKinsey report predicts that in the area of transportation and affordable housing, China would need 1.6 billion to 1.9 billion square meters every year for the next 20 years to build new commercial and residential space to accommodate its surging urban population [51]. One questions the Chinese model of urbanization in terms of its economic, social, and environmental sustainability, especially relating to the adverse effect of intensive (fossil fuel-based) energy consumption, endemic (petrol-powered) congestion, and blocked transport arteries, all of which further contribute towards water and air pollution, increasing toxic wastes, the depletion of natural resources, and general environmental degradation. Several authors describe these effects of Chinese urbanization as infecting Chinese cities with "urban diseases" [57], which others echo as traffic jams, environmental deterioration, housing shortages, employment problems, and public safety challenges [26]. These are all seen as undermining healthy and sustainable development of the country. A fundamental shift in the world economy has occurred, whereby the Chinese policy of rapid urbanization, to some extent fueled by the mass movement of cheap rural labor, has turned China into the world's major manufacturing base. According to a recent McKinsey report, China became the world's largest economy in purchasing-power-parity terms in 2014. As the second largest economy in the world, China's GDP was $66 \%$ that of the United States in 2018. The country became the world's largest exporter of goods in 2009, seeing its share of global goods rising from $1.9 \%$ in 2000 to $11.4 \%$ in 2017. In terms of environmental impact, China has accounted for the world's largest source of carbon emissions since 2006, and currently produces $28 \%$ of annual global emissions. Environmental degradation seems to be driving the country in terms of improving its environmental problems. The air pollution, measured by the PM 2.5 indicator, was 3.7 times higher than for the Organization for Economic Co-operation and Development's (OECD) average in 2016 [59].

In its current phase of development, the Chinese government has shifted the emphasis of the country's economic structure from a manufacturing economy to more of a knowledge-based economy. A recent book contains many case studies relating to the use of mobile devices and human mobility. The cases presented aim to demonstrate the usefulness of big data collected from mobile devices and 
social networks to analyze human mobility. Although the majority of the cases presented are at the level of practice in different cities in China, most of them remain at the level of IoT, whereby data derived using the Internet or connected systems seek to add to the understanding of specific mobility issues [57]. It is unclear how these in the long run will contribute to the holy grail of big (urban) data, significant contributions at the level of urban planning and policy, whereby decisions are based on the added value of the understanding provided from the deeper analysis of big urban datasets, let alone contribute to the higher goal of sustainable urban development. The authors of the work hope that it will offer a vision of urban sustainable form in China, which they see as also encompassing Smart city planning and smart governance [57].

Given that the Fourth Paradigm is driven to a large extent by mobile technology, in terms of the effects on sustainability, and our wholehearted adoption of digital technologies, this probably makes us all culpable if this model is unsustainable-unsustainable in the sense that mobile phones require batteries to work, and these very batteries require the extraction of natural resources, which are currently being won and processed in an unsustainable manner. Apart from this fact, it seems clear that mechanisms need to be developed to readdress the focus of the Chinese model of urbanization towards one that is much more responsible in terms of sustainability. A recent volume of Trialog features China's eco-cities and has articles on eco-cities in China, planning for eco-cities, green building, clean energy, green transport, water management, solid waste management, urban renewal and revitalization, green industries, and green finance. It is encouraging to read that the world's fastest urbanizing country is now beginning to seriously think about the sustainability of the fundamental changes affecting the country. Some see the country may now have a great opportunity to initiate the green and low-carbon transformation of the Chinese urban landscape [58]. In terms of international agreements, the Chinese government is a signatory to the 2016 Paris Climate Deal (COP21), whereby it agrees to cut its $\mathrm{CO}_{2}$ emissions per unit of gross domestic product by $60 \%-65 \%$ from 2005 levels. In addition, there is a commitment to increase the country's share of non-fossil fuels by about $20 \%$ by 2030 . The ultimate benchmark for the country is a departure from coal and oil [58]. Table 2 below shows some indicators relating to urban air quality, whereby countries such as China could improve their position in terms of sustainability. These have been adapted from Annex C (informative) Mapping of indicators to United Nations Sustainable Development Goals (SDGs). As mentioned above, China's PM 2.5 is high. This table covers six indicators relating to urban air quality.

Table 2. Urban air quality indicators relating to the Sustainable Development Goals (SDGs) [60].

\begin{tabular}{|c|c|}
\hline Sustainable Development Goal (2015) & Indicators \\
\hline \multirow[t]{6}{*}{$\begin{array}{l}\text { Goal 11: make cities and human settlements inclusive, } \\
\text { safe, resilient, and sustainable }\end{array}$} & $\begin{array}{l}\text { 8.1 Fine particulate matter (PM 2.5) concentration } \\
\text { (core indicator) }\end{array}$ \\
\hline & $\begin{array}{l}\text { 8.2 Particulate matter (PM 10) concentration (core } \\
\text { indicator) }\end{array}$ \\
\hline & $\begin{array}{l}\text { 8.3 Greenhouse gas emissions measured in tons per } \\
\text { capita (core indicator) }\end{array}$ \\
\hline & $\begin{array}{c}8.5 \mathrm{NO}_{2} \text { (nitrogen dioxide) concentration (supporting } \\
\text { indicator) }\end{array}$ \\
\hline & $\begin{array}{c}8.6 \mathrm{SO}_{2} \text { (Sulphur dioxide) concentration (supporting } \\
\text { indicator) }\end{array}$ \\
\hline & $8.7 \mathrm{O}_{3}$ (ozone) concentration (supporting indicator) \\
\hline
\end{tabular}

The International Organization for Standardization (ISO) report clearly describes how each individual indicator should be calculated and the possible sources for the data required. Standardization of course being essential for meaningful measurement and comparisons.

In relation to urban informatics, some commentators have suggested that China is not to applying the scientific use of data and technology to study the needs, challenges, and opportunities facing 
cities [29]. The focus of Smart city initiatives seems to focus very much on technology. Sometimes, the terminology is ambiguous, with phases such as "informationized planning and management" and "modernized industrial development", which reduces understanding [3]. Ambiguity in these terms makes it very difficult to understand exactly what this all really means. My interpretation is that China has embarked on focusing on the practical application of the IoT throughout the country. As early as 2013, Gubbi, Buyya, and Marusic et al. reported that Shanghai was establishing an IoT center to study technologies and industrial standards. Shen and $\mathrm{Li}$ include some case studies from Shanghai. In addition, funding for industry had been allocated for an IoT and an IoT Union "Sensing China" in Wuxi at the initiative of 60 telecom businesses [10,57]. In this respect, it seems that the Chinese variant on the Smart city parallels quite closely the one propagated in the north by IT companies such as CISCO, Siemens, and IBM, with the technology being the driving force, with the difference being that it is the State that is the incubator for citizens, while in the north, it is businesses that are trying to sell their wares to municipal authorities. Both use big data, Internet, and technology to achieve their goals, but their points of departure may be somewhat different.

What both perspectives lack is a clear link with sustainability, although it is implied in both cases. In the context of the SDGs, there are some commentators who believe that the use of big (urban) data needs to focus much more on outcomes that contribute to a more sustainable urban development. One concept that is widely used in this context is to devise another way of planning, whereby cities in the north and emerging economies look for ways of "leapfrogging", using all the existing know-how (including the lessons from big data), to adopt urban strategies that take into account their urban metabolism. The concept of metabolism is from the natural sciences and aims to emphasize that urban environments are systems whereby a balance needs to be found between natural resources, which also in turn need to be replenished. The idea being, that resources need to be managed to ensure an equilibrium. Allam and Dhunny put sustainability at the heart of their Smart cities' framework, which also includes culture and governance, which together represent, in their view, the basis of livable Smart cities. They argue that the primary focus must be on urban sustainability and livability, which of course are inherent for more inclusive and safe environments, as championed by SDG 11 [38]. A view that Allam and Newman also explore, who suggest that cities need to adopt the SDG 11 goals, targets, and indicators as they adapt and integrate big data and IoT to shape their futures in a sustainable manner. They spell out what they mean by culture, metabolism, and governance. Culture is about how cities can build their urban history to establish meaning behind the connection between people and place in a given city. Metabolism is about radically reducing the excessive resource consumption and waste in cities-the idea that cities should be conscious of their impact on the environment and that they should take measures to mitigate such adverse impacts. Governance is about creating new partnerships between local and regional government, business, and community to realize urban solutions. The framework is not technology-driven but is citizen-driven, combining shared corporate-centered solutions. The point being, unlike some Smart city solutions, it is not information and communication technology (ICT) that is driving the process [61].

\section{Capacity Building and Training of Urban Managers}

The adherents of this approach see it as more likely to lead to achieving the 2030 UN Sustainable Development Agenda. The economic growth of cities must ensure that development encompasses inclusivity, safety, resilience, and sustainability, or it will ultimately fail. The ramifications of urbanization mentioned earlier mean that it is essential to seek ways of using the IoT, big (urban) data, and urban informatics to inform urban development and urban policy worldwide. To achieve this, there are some conditions must be met in terms of the institutional framework, both at the city and national levels. These are especially crucial in the area of the collection, storage, processing, analysis, and visualization of big (urban) data. Urban managers across the board need to enhance their skillsets in order to make the most of the increasing amounts of big (urban) data generated by cities today. It is something that higher education institutes need to address as a matter of urgency by introducing 
new innovative education and training programs that target filling the current skillset gap of urban managers. This is particularly important in the area of developing innovative and practice-based curricula, aiming to equip urban managers with the appropriate data science skills to enable them to get the most out of big (urban) data in their (future) data enhanced working environments.

Enticed by the current hype around ICTs offering off-the-peg solutions to municipalities that wish to implement Smart city solutions, many cities have tried to adopt such solutions. One striking article by Giest looks at number of cases (including Copenhagen, London, Malmö, Oxford, and Vienna) of municipalities aiming to use big data to address an urban policy issue. Her main finding highlights the institutional complexity underlying big data integration. It was simply beyond the management structures of the cities involved. The problem seems to boil down to the institutional context, which is unable to create an appropriate institutional setting to accommodate big data. This is linked with the limited capacity (read skillset) of individuals or local government departments to access and utilize data-based information. The current practice being that city governments in these circumstances are forced to rely on external (ICT) experts to upholster the limited technical capacity in data collection and urban analytics. In other words, implementing big data analytics results in more contracting out in local government, because of the inability of current urban managers to make sense of the data. This also undermines collaboration between departments and with communities [39].

Some authors have pointed to the inability of local government to handle and manage big (urban) data as a fundamental challenge. The solution that they offer is to create two institutions. The suggestion is to have one entity to collect and store big (urban) data and another one to process the information using urban analytics tools. Estiri and Afzalan argue that there should be data centers for the former and a second unit called the Analytics Core that transfers big (urban) data into information and presents it as knowledge for urban decision makers. These two institutions need to be clearly located in the organization(s) that they serve, and the issues of their best location and financial and administrative sustainability, and who should work in them still need working out. The urban Analytics Core is then a policy-research entity and does not operate in the same sphere as the many labs that have emerged in recent years. It is a hybrid entity, operating independently between local government and other knowledge institutions, such as universities, businesses, and even public libraries. Its raison d'être to translate new urban data sources and big data for urban policy and decision making [43].

The foregoing discussion raises some issues that need addressing. Firstly, much thought needs to be given to accommodating such specialized institutions dealing with big (urban) data in existing metropolitan environments. Here, there may be collaboration with other municipalities to share resources, especially as these days, cloud and edge computing seem to offer more and more opportunities to pay attention to the potential cost implications of big data management and processing. Another issue for emerging economies would be whether the local computing infrastructure can support the model Estiri and Afzalan are proposing. Then, there is there is the previously mentioned issue on the need to provide urban mangers (worldwide) with the appropriate skillset to be able to fully utilize and understand what is required to implement policy making based on knowledge derived from big (urban) data. Here, educational institutes have a key role to play to address this fundamental bottleneck.

Table 3 below gives an overview of the main Master's in Urban Informatics that are currently available. Most of them seem to focus on developing computer science skills of data modelling and data visualization. What they seem to lack is a program that covers urban management and development (in emerging economies). A niche seems to exist for a specific urban informatics Master's focusing on emerging economies and sustainable urban development.

The Amsterdam Institute for Advanced Metropolitan Solutions does offer the MSc Metropolitan Analysis, Design, and Engineering (MADE), which deals with the complex challenges of cities. This two-year master programme is run as a joint degree programme in Amsterdam with Wageningen University \& Research and Delft University of Technology. In terms of urban data, the Amsterdam Institute for Advanced Metropolitan Solutions also run some courses, but they do not lead to a Masters' degree in Urban Informatics. The focus of the institute seems to be putting theory into practice in 
Amsterdam, much in the way New York University, Center for Urban Science and Progress (CUSP) uses New York as its lab (see Figure 2 below).

Table 3. Overview of Master's in Urban Informatics.

\begin{tabular}{|c|c|}
\hline Institution, Name of Course, and Duration & Description \\
\hline $\begin{array}{c}\text { King's College London } \\
\text { Urban Informatics MSc } \\
\text { https://www.kcl.ac.uk/study/postgraduate/taught- } \\
\text { courses/urban-informatics-msc } \\
\text { One year }\end{array}$ & $\begin{array}{l}\text { Deals with the technical, analytical, and } \\
\text { communication skills required to conduct effective } \\
\text { urban data analysis, using detailed case study topics } \\
\text { and the communication of results to effect change. }\end{array}$ \\
\hline $\begin{array}{c}\text { Northeastern University, College of Social Sciences } \\
\text { and Humanities, School of Public Policy and } \\
\text { Urban Affairs } \\
\text { MSc in Urban Informatics (MSUI) } \\
\text { https://cssh.northeastern.edu/policyschool/urban- } \\
\text { informatics/ } \\
32 \text { semester hours }\end{array}$ & $\begin{array}{l}\text { Cities are embracing "big data"; statistical modelling; } \\
\text { and visualization, mapping, and spatial analysis, and } \\
\text { the implementation of apps and sensor systems to } \\
\text { track, understand, and improve urban life. Such a } \\
\text { change requires a new generation of experts who can } \\
\text { navigate the technical and conceptual challenges } \\
\text { presented by the city. This program offers training in } \\
\text { data analytics-including quantitative analysis, data } \\
\text { mining, machine learning, and data visualization. }\end{array}$ \\
\hline $\begin{array}{c}\text { New York University, Center for Urban Science } \\
\text { and Progress (CUSP) } \\
\text { MSc in Applied Urban Science and Informatics } \\
\text { https://cusp.nyu.edu/masters-degree/ } \\
\text { One-year, three-semester, 30-credit MSc program }\end{array}$ & $\begin{array}{l}\text { This course is an interdisciplinary study of urban } \\
\text { science and informatics focusing on applying } \\
\text { technical skills to urban problems. Topics include } \\
\text { courses in urban science, urban informatics, and } \\
\text { information and communication technology in cities. } \\
\text { It provides participants with the ability to use } \\
\text { large-scale data from a variety of sources to } \\
\text { understand and address real-world urban issues. }\end{array}$ \\
\hline $\begin{array}{l}\text { University of Warwick, Centre for Interdisciplinary } \\
\text { Methodologies } \\
\text { Urban Analytics and Visualization (MSc) } \\
\text { https://warwick.ac.uk/study/postgraduate/courses- } \\
\text { 2019/uav } \\
\text { One year }\end{array}$ & $\begin{array}{l}\text { Represents an emerging interdisciplinary approach to } \\
\text { addressing urban challenges. The course develops } \\
\text { practical skills needed-such as data analytics and } \\
\text { visualization techniques-combining practice with } \\
\text { theory and a methodological understanding of urban } \\
\text { systems. The course was previously given as Urban } \\
\text { Informatics and Analytics. }\end{array}$ \\
\hline
\end{tabular}

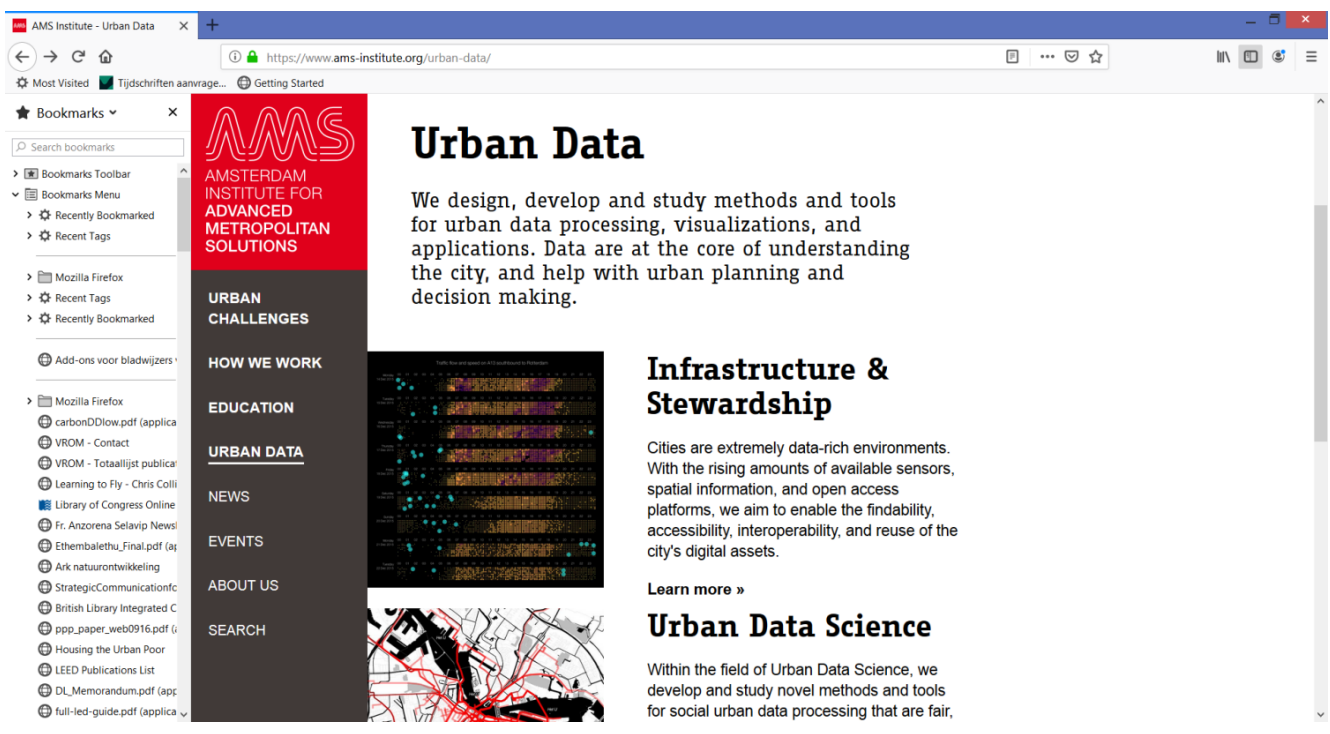

Figure 2. Screen shot of the urban data section of the Amsterdam Institute for Advanced Metropolitan Solutions. 
Many people are attracted to the hype behind urban informatics, which to date has been dominated by data science. The skillset of current urban professionals is not sufficient to fully exploit the potential of urban informatics expressed by many. There is a need to educate urban professionals in a combination of skills. A joint Masters degree focusing on providing knowledge and skills on sustainable urban development and urban informatics could have the following topics, as shown in Table 4.

Table 4. Topics for a joint Master's in Urban Informatics and Sustainable Urban Development.

\begin{tabular}{cc}
\hline Urban Sustainable Development & Urban Informatics \\
\hline Housing and Infrastructure & Data collection and management \\
\hline Land management & Data processing (analytics) \\
\hline City management and development & Urban data visualization \\
\hline Regional and economic development & Urban knowledge lab \\
\hline Climate Change and Urban Resilience & Urban Apps for deployment in the field \\
\hline
\end{tabular}

\section{Emerging Economies and Apps}

Table 5 below gives some of the examples mentioned in the literature reviewed of ways in which the IoT and ICT has been deployed to address urban problems in emerging economies. The UN Global Pulse is one pioneering initiative that collects information on successful initiatives in emerging economies. Its mission being to promote awareness of the opportunities big data presents for sustainable development and humanitarian action, forge public-private data sharing partnerships, generate high-impact analytical tools and approaches through its network of pulse labs, and drive broad adoption of useful innovations across the UN System. (https://www.unglobalpulse.org/about-new). They list projects sorted by theme and pulse labs to test and pilot real-time monitoring approaches at the country level and support the adoption of proven approaches.

Table 5. Examples of the use of (big) data and mobile technology being used to address urban problems in emerging economies.

\begin{tabular}{|c|c|}
\hline Name of Initiative & Description \\
\hline $\begin{array}{c}\text { Rio Operations Center } \\
{[16,22,44]}\end{array}$ & $\begin{array}{l}\text { The local government in Rio de Janeiro has a center that aims } \\
\text { to use technology and big data to improve the running of the } \\
\text { city in the areas of transport management, natural disaster } \\
\text { mitigation, mass transit systems, and the management of } \\
\text { slum areas. }\end{array}$ \\
\hline $\begin{array}{l}\text { Open data for Informal Settlements } \\
\qquad[62]\end{array}$ & $\begin{array}{l}\text { Research in Mumbai, India, that demonstrated how open data } \\
\text { resources can be used to understand urbanization better and } \\
\text { use that information to help integrate informal settlements into } \\
\text { the formal planning and urban management processes. }\end{array}$ \\
\hline $\begin{array}{l}\text { Bájale al Acoso } \\
{[63]}\end{array}$ & $\begin{array}{l}\text { A mobile platform used to report sexual harassment in the } \\
\text { public transport system in Quito, Ecuador. }\end{array}$ \\
\hline $\begin{array}{l}\text { Facial Recognition System to Automate } \\
\text { payment on local buses } \\
\text { [63] }\end{array}$ & Yinchuan, China \\
\hline $\begin{array}{l}\text { Addressing the Unaddressed } \\
\text { [63] }\end{array}$ & $\begin{array}{l}\text { In Kolkata, India, a non-profit social enterprise provides } \\
\text { unique postal addresses to slum dwellers. }\end{array}$ \\
\hline $\begin{array}{l}\text { Open Traffic Platform } \\
\text { [63] }\end{array}$ & $\begin{array}{l}\text { In Cebu City, the Philippines, a system that optimizes the } \\
\text { timing of traffic signals in peak hours based on GPS data from } \\
\text { the smartphones of drivers for the taxi service Grab. }\end{array}$ \\
\hline
\end{tabular}


Table 5. Cont.

\begin{tabular}{|c|c|}
\hline Name of Initiative & Description \\
\hline $\begin{array}{l}\text { Combining satellite and survey data to } \\
\text { study Indian slums [64] }\end{array}$ & $\begin{array}{l}\text { The research shows the utility of satellite data for locating } \\
\text { undocumented settlements, that there are local variations in } \\
\text { living conditions and service levels, and urban policy needs to } \\
\text { target the neighborhood level instead of individuals. }\end{array}$ \\
\hline $\begin{array}{l}\text { Mobile for Good (M4G) } \\
\qquad[52]\end{array}$ & $\begin{array}{c}\text { The project uses mobile phones to connect people to job } \\
\text { information. The first project started in Nairobi, Kenya. Plans } \\
\text { exist at OneWorld U.K. to expand the scheme across Africa and } \\
\text { other emerging economies. }\end{array}$ \\
\hline $\begin{array}{l}\text { Babajob } \\
\quad[52]\end{array}$ & $\begin{array}{c}\text { A job site started in Bangalore, India, in } 2005 \text { that has } \\
\text { expanded to six further cities (New Deli, Mumbai, Hyderabad, } \\
\text { Than, Jaipur, and Chennai) }\end{array}$ \\
\hline $\begin{array}{l}\text { Fresh Air Benin } \\
{[8]}\end{array}$ & $\begin{array}{l}\text { Utilizes a network of air quality sensors to record and } \\
\text { disseminate data every } 20 \text { minutes using mobile connectivity. }\end{array}$ \\
\hline $\begin{array}{l}\text { Networked fire/smoke alarms } \\
\text { [8] }\end{array}$ & $\begin{array}{l}\text { Located in high density urban slums/informal settlements } \\
\text { (Kenya/South Africa). }\end{array}$ \\
\hline $\begin{array}{c}\text { Echo Mobile-fleet management for public } \\
\text { safety/digital matatus } \\
(\text { www.digitalmatatus.com }) \\
{[8,37]}\end{array}$ & $\begin{array}{c}\text { Sensor-connected matatus (mini-buses). Tracking speed, } \\
\text { acceleration, and braking to limit dangerous operation of } \\
\text { public transport (Kenya). }\end{array}$ \\
\hline $\begin{array}{c}\text { Understanding the evolution of slums in } \\
\text { Ahmedabad through the integration of } \\
\text { survey datasets } \\
\text { [65] }\end{array}$ & $\begin{array}{c}\text { A paper seeking to explain the development of slums in } \\
\text { Ahmedabad City, India, by comparing some publicly available } \\
\text { datasets from 1990-2012. It highlights the importance of such } \\
\text { surveys to employ standardized methods in their collection } \\
\text { and storage of data in their databases to facilitate } \\
\text { meaningful comparisons. }\end{array}$ \\
\hline
\end{tabular}

My own institute, the Institute for Housing and Urban Development (IHS), currently has a project in India that is aiming to help women in a resettlement area of Chennai to use ICTs. The project aims to develop and implement ICT technology that will do the following:

1. Raise affected women's awareness of their rights;

2. Help women connect with their community and provide them access to support groups;

3. Give women information about government services and program in and around the new resettlement site;

4. Support women in creating business opportunities and reaching clients.

In addition to developing ICT technology through action research, the team will develop a training course on resettlement, gender, and communication (https:/www.ihs.nl/en/news/ict-empoweringwomen-chennai-resettlement-areas). Given India's current technology driven development, one expects that there may be a lot of home-grown ICT innovations that can be adopted/adapted for this project.

In emerging economies, especially in countries such as India, there is a huge reservoir of young Internet savvy inhabitants with mobile devices who could be the ones to carry the digital revolution further by facilitating the deployment of a wide range of easy to implement apps to inform city authorities in a social, environmental, equitable, and resilient fashion in the name of sustainable development. In the coming years, such apps will be the most important source for urban innovation in emerging economies, as they are duplicable in other urban contexts using relatively speaking modest investments in terms of hardware and software. It may be useful to have some local labs in situ in emerging economies to stimulate the cross-fertilization of easy to implement ICT solutions in new locations/contexts. 
One of the striking features around the debate around the Fourth Paradigm is the high degree of hype (claims), which contrasts to the many challenges. The whole debate suffers from too many claims being made about how the application of big (urban) data can impact on urban policy making. Big urban data without a doubt will be used to enhance the understanding of often complex social, economic, and environmental processes in cities. However, it will never be used alone, and it is questionable whether the algorithms of the future will ever suffice to explain and predict what is, and what is going to happen in cities. My expectation is there will be a coming together of traditional qualitative survey based-research techniques, which have some limitations, especially in terms of the limited size of the population being studied. Qualitative methods, the argument goes, lack the more granular view inherent in big (urban) data. The number, volume, and variety of data sources about cities will continue to grow rapidly, especially from mobile data sources, and it will be the part of the work of urban professionals to harness that data, to improve city management. The following figures help to illustrate the significance of mobile devices: during the first quarter of 2015, worldwide mobile phone subscriptions reached 7.2 billion, with Africa and Asia having three quarters of the new subscriptions [28]. Another source gives the figure of 11.47 billion mobile users in China [66].

Clearly, it is this increase in mobile phones in emerging economies that will offer these cities the chance to connect to their citizens at a relatively low cost. That is why the further deployment of suitable apps to address specific urban issues seems to be a good way to move forward to improve city life across the board. It may well be what will happen in the IHS project in Chennai. Some argue that emerging economies need to use so called "frugal innovation" when implementing new technology [66]. This implies finding ways to innovate even when there is a lack of the sophisticated technological infrastructure comparable to that which is available in the north. Currently, there are some privately funded initiatives to increase worldwide Internet coverage using satellites, which may alleviate the issue of Internet access in emerging economies [67]. It is probably in the field of the visualization of big (urban) data that there will be much more research to offer urban managers easy ways to understand and present overviews showing the findings of the analysis of such big (urban data), particularly in the development of intuitive dashboards.

\section{Conclusions}

When considering the impacts of both the "digital revolution" and the (rapid) onset of urbanization in China, the north, and in emerging economies, the inescapable conclusion must be that it is difficult to draw any specific lessons. In this article, an attempt was made to understand the differences in the three approaches described. Clearly, what has happened in terms of urbanization in China is something that may be unique to history. Therefore, drawing lessons for other regions may not be that straightforward. In addition, the nature of the implementation of the digital revolution in China, which is basically driven by the state, raises many questions relating to its replicability elsewhere. Without question, China is investing heavily in new technology to address some of its problems. However, some suggest that the rapid pace of its urban development may ultimately undermine the country' progress regarding the wicked problems, especially those related to sustainable development.

Like China, the north has its sponsors for technology-driven Smart cities, namely large multinational corporations that aim to offer municipalities off-the-peg solutions on how to run their cities. As has been pointed out above, one of the major constraints is the gap in the skillsets of many urban managers. This limits the ability of municipal organizations to take on board the kinds of solutions that urban informatics/analytics may offer to those managing our cities. This lack of capacity appears to be at two levels, namely: (1) the storage and processing of big (urban) data and (2) the application of urban informatics/analytics to extract meaningful outcomes from big (urban) data to inform policy. It is argued that this is an area in which universities and higher education institutions may have a role to fill this gap in the capacity of municipal organizations, by offering Masters courses combing urban management skills with a range of data science skills inherent in urban informatics. The point being that urban managers need to have both skillsets to be able to inform urban policy decisions. 
Emerging economies find themselves in a different position. There are plenty of examples at the level of apps whereby new technologies can improve in a meaningful way how cities address some urban issues in a specific city. There is a relatively low threshold to roll out for such apps. Equally important for their success is the ubiquity of mobile phones worldwide. However, it all seems to be rather piecemeal, and in no way at the level of the ambitions of China or the north. The obvious reason being the lack of an appropriate technological infrastructure and a lack of financial resources. Three different strands of Smart city initiatives exist, one in China, one in the north, and one in emerging economies. Each have their own trajectories of implementation. That is why one size will not fit all.

Supplementary Materials: The following are available online at http://www.mdpi.com/2624-6511/3/2/11/s1, Figure S1: Big (Urban) Data Word Cloud generated by the Wordle App. Figure S2. Urban Informatics/Analytics Word Cloud generated by the Wordle App. Figure S3. Hype around Urban Informatics/Analytics Word Cloud generated by the Wordle app. Figure S4. Challenges around Urban Informatics/Analytics Word Cloud generated by the Wordle app. Table S1. Summary of definitions of the Internet of Things (IofT), Big (Urban) Data and Urban Informatics/Analytics. Table S2. Overview of the Hype and Challenges around Big Data and Urban Informatics/Analytics.

Funding: No funding was received for this study.

Conflicts of Interest: The author declares no conflict of interest.

\section{References}

1. BBC. The Andrew Marr Show on the 3rd March 2019, London, UK. 2019. Available online: https: //www.youtube.com/watch?v=zqNB2fpG3xQ (accessed on 8 May 2019).

2. United Nations. United Nations: Meetings Coverage and Press Releases: Press Releases: Secretary General: Statements and Messages: SG/SM/14249-ENV/DEV/1276-HAB/277: 23 April 2012. 2012. Available online: https://www.un.org/press/en/2012/sgsm14249.doc.htm (accessed on 1 May 2019).

3. Dogan, O.; Gurcan, O.F. Applications of big data and green IoT-enabling technologies for smart cities. In Handbook of Research on Big Data and the IofT; (Advances in Data Mining and Database Management (ADMDM) book series); Kaur, G., Tomar, P., Eds.; IGI Global: Hershey, PA, USA, 2019; pp. $22-41$.

4. Dourish, P. The internet of urban things. In Code and the City (Regions and Cities); Kitchin, R., Ed.; Routledge: Abingdon, UK, 2016; pp. 27-48.

5. Schintler, L.A.; Chen, Z. Introduction. In Big Data for Regional Science (Routledge Advances in Regional Economics, Science and Policy); Schintler, L.A., Chen, Z., Eds.; Routledge: Abingdon, UK, 2018; pp. 1-8.

6. Schintler, L.A. The constantly shifting face of the digital divide: Implications for big data, urban informatics, and regional science. In Big Data for Regional Science (Routledge Advances in Regional Economics, Science and Policy); Schintler, L.A., Chen, Z., Eds.; Routledge: Abingdon, UK, 2018; pp. 336-346.

7. Bibri, S.E. Smart Sustainable Cities of the Future: The Untapped Potential of Big Data Analytics and Context-Aware Computing for Advancing Sustainability; (The Urban Book Series); Springer: Cham, Switzerland, 2018.

8. Biggs, P.; Garrity, J.; LaSalle, C.; Polomska, A. Harnessing the Internet of Things for Global Development; International Telecommunications Union (ITU): Geneva, Switzerland, 2016; Available online: https://www. itu.int/en/action/broadband/Documents/Harnessing-IoT-Global-Development.pdf (accessed on 1 May 2019).

9. Ge, M.; Bangui, H.; Buhnova, B. Big data for Internet of Things: A survey. Future Gener. Comput. Syst. 2017, 87, 601-614. [CrossRef]

10. Gubbi, J.; Buyya, R.; Marusic, S.; Palaniswami, M. Internet of Things (IoT): A vision, architectural elements, and future directions. Future Gener. Comput. Syst. 2013, 29, 1645-1660. [CrossRef]

11. Hashem, I.A.T.; Chang, V.; Anuar, N.B.; Adewole, K.; Yaqoob, I.; Gani, A.; Ahmed, E.; Chiroma, H. The role of big data in smart city. Int. J. Inf. Manag. 2016, 36, 748-758. [CrossRef]

12. Mahdavinejad, M.S.; Rezvan, M.; Barekatain, M.; Adibi, P.; Barnaghi, P.; Sheth, A.P. Machine learning for internet of things data analysis: A survey. Digit. Commun. Netw. 2018, 4, 161-175. [CrossRef]

13. Uraia. Brussels Guidelines 2018: Using Data to Empower Cities and Their Citizens; (Citizenship Series); Uraia: Malaga, Spain, 2018; Available online: https://uraia.org/documents/306/Guidelines_Brussels_2018_FINAL. pdf (accessed on 1 May 2019). 
14. Thakuriah, P.; Tilahun, N.Y.; Zeller, M. Big data and urban informatics: Innovations and challenges to urban planning and knowledge discovery. In Seeing Cities through Big Data: Research, Methods and Applications in Urban Informatics; Thakuriah, P., Tilahun, N., Zellner, M., Eds.; Springer: Cham, Switzerland, 2017; pp. 11-45.

15. Johnson, T.P.; Smith, T.W. Big data and survey research: Supplement or substitute. In Seeing Cities through Big Data: Research, Methods and Applications in Urban Informatics; Thakuriah, P., Tilahun, N., Zellner, M., Eds.; Springer: Cham, Switzerland, 2017; pp. 113-125.

16. Barkham, R.; Bokhari, S.; Saiz, A. Using Big Data: City Management and Real Estate Markets; Urban Economics Lab, MIT Center for Real Estate and DUSP: Cambridge, MA, USA, 2018; Available online: https://mitcre. mit.edu/wp-content/uploads/2018/01/URBAN-DATA-AND-REAL-ESTATE-JAN-2018-1.pdf (accessed on 1 May 2019).

17. Al Nuaimi, E.; Al Neyadi, H.; Mohamed, N.; Al-Jaroodi, J. Applications of big data to smart cities. J. Internet Serv. Appl. 2015, 6, 1-15. [CrossRef]

18. Chowdhury, P.K.R.; Sutherland, S.H.; Ernst, K.M.; Pawlowski, A.; Schmidt, E.H.; Caspersen, J.R.; Zhao, Z.; Bhaduri, B.L. Big data in emerging cities. In Big Data for Regional Science; Schintler, L.A., Chen, Z., Eds.; Routledge: London, UK, 2018; pp. 277-291. Available online: https://www.osti.gov/servlets/purl/1376332 (accessed on 13 April 2019).

19. Alharthi, A.; Krotov, V.; Bowman, M. Addressing barriers to big data. Bus. Horiz. 2017, 60, $285-292$. [CrossRef]

20. Bennett, R.M.; Pickering, M.; Sargent, J. Transformations, transitions, or tall tales? A global review of the uptake and impact of NoSQL, blockchain, and big data analytics on the land administration sector. Land Use Policy 2019, 83, 435-448. [CrossRef]

21. Bibri, S.E. The IoT for smart sustainable cities of the future: An analytical framework for sensor-based big data applications for environmental sustainability. Sustain. Cities Soc. 2018, 38, 230-253. [CrossRef]

22. Kitchin, R. Big data, new epistemologies and paradigm shifts. Big Data Soc. 2014, 1-12. [CrossRef]

23. Lim, C.; Kim, K.; Maglio, P.P. Smart cities with big data: Reference models, challenges and considerations. Cities 2018, 82, 86-99. [CrossRef]

24. Monroe, T. Big Data and Thriving Cities: Innovations in Analytics to Build Sustainable, Resilient Equitable and Livable Cities; World Bank: Washington, DC, USA, 2017; Available online: http://documents.worldbank.org/curated/en/842181488514624285/pdf/113147-WP-P152206-PUBLICWBG-BigData-URBAN-Final-online.pdf (accessed on 13 April 2019).

25. Osman, A.M.S. A novel big data analytics framework for smart cities. Future Gener. Comput. Syst. 2019, 91, 620-633. [CrossRef]

26. Pan, Y.; Tian, Y.; Liu, X.; Gu, D.; Hua, G. Urban big data and the development of city intelligence. Engineering 2016, 2, 171-178. [CrossRef]

27. Wu, Y.; Zhang, W.; Shen, J.; Mo, Z.; Peng, Y. Smart city with Chinese characteristics against the background of big data: Idea, action and risk. J. Clean. Prod. 2018, 173, 60-66. [CrossRef]

28. Krishnamurthy, R.; Smith, K.L.; Desouza, K.C. Urban informatics: Critical data and technology considerations. In Seeing Cities through Big Data: Research, Methods and Applications in Urban Informatics; Thakuriah, P., Tilahun, N., Zellner, M., Eds.; Springer: Cham, Switzerland, 2017; pp. 163-188.

29. Wu, J.S.; Zhang, R. Seeing Chinese cities through big data and statistics. In Seeing Cities through Big Data: Research, Methods and Applications in Urban Informatics; Thakuriah, P., Tilahun, N., Zellner, M., Eds.; Springer: Cham, Switzerland, 2017; pp. 291-309.

30. Goodspeed, R. Urban informatics: Defining an emerging field. In Big Data for Regional Science (Routledge Advances in Regional Economics, Science and Policy); Schintler, L.A., Chen, Z., Eds.; Routledge: Abingdon, UK, 2018; pp. 324-335.

31. Foth, M.; Choi, J.H.; Satchell, C. Urban informatics. Presented at ACM Conference on Computer Supported Cooperative Work Paper CSCW 2011, Hangzhou, China, 19-23 March 2011; 2011. Available online: https://www.researchgate.net/publication/220879616_Urban_informatics (accessed on 2 May 2019).

32. Barns, S. Visions of urban informatics: From proximate futures to data-driven urbanism. Fibrecult. J. 2017, 29, 1-20. Available online: http://fibreculturejournal.org/wp-content/pdfs/FCJ-214SarahBarns.pdf (accessed on 1 May 2019). [CrossRef]

33. Batty, M. Big data and the city. Built Environ. 2016, 42, 321-337. [CrossRef]

34. Kitchin, R. The real-time city? Big data and smart urbanism. Geojournal 2014, 79, 1-14. [CrossRef] 
35. Kitchin, R. The ethics of smart cities and urban science. Philos. Trans. R. Soc. A 2016, 374, 1-15. [CrossRef]

36. Kontokosta, C.E. Urban informatics in the science and practice of planning. J. Plan. Educ. Res. 2018, 1-14. [CrossRef]

37. Singleton, A.D.; Spielman, S.E.; Folch, D.C. Urban Analytics; (Spatial Analytics and GIS Series); Sage: London, UK, 2018.

38. Allam, Z.; Dhunny, Z.A. On big data, artificial intelligence and smart cities. Cities 2019, 89, 80-91. [CrossRef]

39. Giest, S. Big data analytics for mitigating carbon emissions in smart cities: Opportunities and challenges. Eur. Plan. Stud. 2017, 25, 941-957. [CrossRef]

40. Glaeser, E.L.; Kominers, S.D.; Luca, M.; Naik, N. Big data and big cities: The promises and limitations of improved measures of urban life. Econ. Inq. 2018, 56, 114-137. [CrossRef]

41. Thakuriah, P.; Tilahun, N.Y.; Zeller, M. Introduction to seeing cities through big data: Research, methods and applications in urban informatics. In Seeing Cities through Big Data: Research, Methods and Applications in Urban Informatics; Thakuriah, P., Tilahun, N., Zellner, M., Eds.; Springer: Cham, Switzerland, 2017; pp. 1-9.

42. Vyas, S.; Bhargava, D. Big data utilization, benefits, and challenges for smart city implementation. In Handbook of Research on Big Data and the IofT; (Advances in Data Mining and Database Management (ADMDM) Book Series); Kaur, G., Tomar, P., Eds.; IGI Global: Hershey, PA, USA, 2019; pp. 42-54.

43. Estiri, H.; Afzalan, N. Towards data-driven cities: Incorporating big data into urban management. In Big Data for Regional Science; Schintler, L.A., Chen, Z., Eds.; Routledge: London, UK, 2018; pp. 204-314.

44. Ali, A.; Qadir, J.; ur Rasool, R.; Sathiaseelan, A.; Zwitter, A.; Crowcroft, J. Big data for development. Big Data Anal. 2016, 1, 1-24. [CrossRef]

45. Hao, J.; Zhu, J.; Zhong, R. The rise of big data on urban studies and planning practices in China: Review and open research issues. J. Urban Manag. 2015, 4, 92-124. [CrossRef]

46. Silva, B.N.; Khan, M.; Han, K. Towards sustainable smart cities: A review of trends, architectures, components, and open challenges in smart cities. Sustain. Cities Soc. 2018, 38, 697-713. [CrossRef]

47. Zanella, A.; Bui, N.; Castellani, A.; Vangelista, L.; Zorzi, M. Internet of Things for smart cities. IEEE Internet Things J. 2014, 1, 22-32. [CrossRef]

48. Crato, N.; Paruolo, P. Data-Driven Policy Impact Evaluation: How Access to Microdata is Transforming Policy Design; Springer Open: Cham, Switzerland, 2019. [CrossRef]

49. Barthelemy, M. The Structure and Dynamics of Cities: Urban Data Analysis and Theoretical Modeling; Cambridge University Press: Cambridge, UK, 2016.

50. Venables, W.N.; Smith, D.M.; R Core Team. An introduction to R: Notes on R: A Programming Environment for Data Analysis and Graphics; Version 3.6 .3 (2020-02-29); The Comprehensive R Archive Network, (CRAN): Vienna, Austria, 2020; Available online: https://cran.r-project.org/doc/manuals/r-release/R-intro.pdf (accessed on 14 March 2020).

51. Dobbs, R.; Smit, S.; Remes, J.; Manyika, J.; Roxburgh, C.; Restrepo, A. Urban World: Mapping the Economic Power of Cities; McKinsey Global Institute: New York, NY, USA, 2011; Available online: https:/www.mckinsey.com/ \{\}/media/McKinsey/Featured\%20Insights/Urbanization/ Urban\%20world/MGI_urban_world_mapping_economic_power_of_cities_full_report.ashx (accessed on 1 May 2019).

52. Omole, D.W. Harnessing information and communication technologies (ICTs) to address urban poverty: Emerging open policy lessons for the open knowledge economy. Inf. Technol. Dev. 2013, 19, 86-96. [CrossRef]

53. Kharrazi, A.; Qin, H.; Zhang, Y. Urban big data and sustainable development goals: Challenges and opportunities. Sustainability 2016, 8, 1293. [CrossRef]

54. United Nations. Transforming Our World the 2030 Agenda for Sustainable Development: A/RES/70/1; United Nations, Division for Sustainable Development: New York, NY, USA, 2015; Available online: https://www.un.org/en/development/desa/population/migration/generalassembly/docs/ globalcompact/A_RES_70_1_E.pdf (accessed on 11 May 2019).

55. Hamnett, C. Is Chinese urbanisation unique? Urban Stud. 2020, 57, 690-700. [CrossRef]

56. Hu, R. The state of smart cities in China: The case of Shenzhen. Energies 2019, 12, 4375. [CrossRef]

57. Shen, Z.; Li, M. Big Data Support of Urban Planning and Management: The Experience in China; (Advances in Geographic Information Science); Springer Nature: Cham, Switzerland, 2018.

58. Steinberg, F.; Gouwen, D. Eco-cities in China: An urban revolution in the making. Trialog 2018, 1-2, 4-10. 
59. Woetzel, J.; Seong, J.; Leung, N.; Ngai, J.; Manyika, J.; Madgavkar, A.; Lund, S.; Mironenko, A. China and the World: Inside the Dynamics of a Changing Relationship; McKinsey Global Institute: New York, NY, USA, 2019; Available online: https://www.mckinsey.com/ \{\}/media/mckinsey/featured\%20insights/china/china\%20and\% 20the $\% 20$ world $\% 20$ inside $\% 20$ the $\% 20$ dynamics $\% 20$ of $\% 20$ a $\% 20$ changing $\% 20$ relationship/mgi-china-andthe-world-full-report-june-2019-vf.ashx (accessed on 15 March 2020).

60. ISO. Sustainable Development of Communities: Indicators for City Services and Quality of Life, 2nd ed.; (International Standard ISO 37120:2018(E)); International Organization for Standardization (ISO): Geneva, Switzerland, 2018.

61. Allam, Z.; Newman, P. Redefining the smart city: Culture, metabolism and governance. Smart Cities 2018, 1, 4-25. [CrossRef]

62. Chakraborty, A.; Wilson, B.; Sarraf, S.; Jana, A. Open data for informal settlements: Toward a user's guide for urban managers and planners. J. Urban Manag. 2015, 4, 74-91. [CrossRef]

63. Global Future Council on Cities and Urbanization. Data driven cities: 20 Stories of Innovation; World Economic Forum: Cologny/Geneva, Switzerland, 2017; Available online: http://www3.weforum.org/docs/Top20_ Global_Data_Stories_report_2017.pdf (accessed on 13 April 2019).

64. Rains, E.; Krishna, A.; Wibbels, E. Combining satellite and survey data to study Indian slums: Evidence on the range of conditions and implications for urban policy. Environ. Urban. 2018, 31, 267-292. [CrossRef]

65. Killemsetty, N. Understanding the evolution of slums in Ahmedabad through the integration of survey data sets. In Innovation in Urban Development: Incremental Housing, Big Data, and Gender; (A New Generation of Ideas); Garland, A.M., Ed.; Wilson Center: Washington, DC, USA, 2013; pp. 127-145. Available online: https://www.wilsoncenter.org/sites/default/files/CUSP_130604_Innovation\% 20in\%20Urban\%20Poverty_rpt\%201106_0.pdf (accessed on 10 June 2019).

66. Shen, Z. Overview: Big data support for urban planning and management in China. In Big Data Support of Urban Planning and Management: The Experience in China (Advances in Geographic Information Science); Shen, Z., Li, M., Eds.; Springer Nature: Cham, Switzerland, 2018; pp. 1-15.

67. Hurst, N. Why Satellite Internet is the New Space Race. PC Mag. 2018. Available online: https://www.pcmag. com/article/362695/why-satellite-internet-is-the-new-space-race (accessed on 1 June 2019).

(C) 2020 by the author. Licensee MDPI, Basel, Switzerland. This article is an open access article distributed under the terms and conditions of the Creative Commons Attribution (CC BY) license (http://creativecommons.org/licenses/by/4.0/). 